\title{
Historein
}

Vol 14, No 2 (2014)

Historein 14/2 (2014)

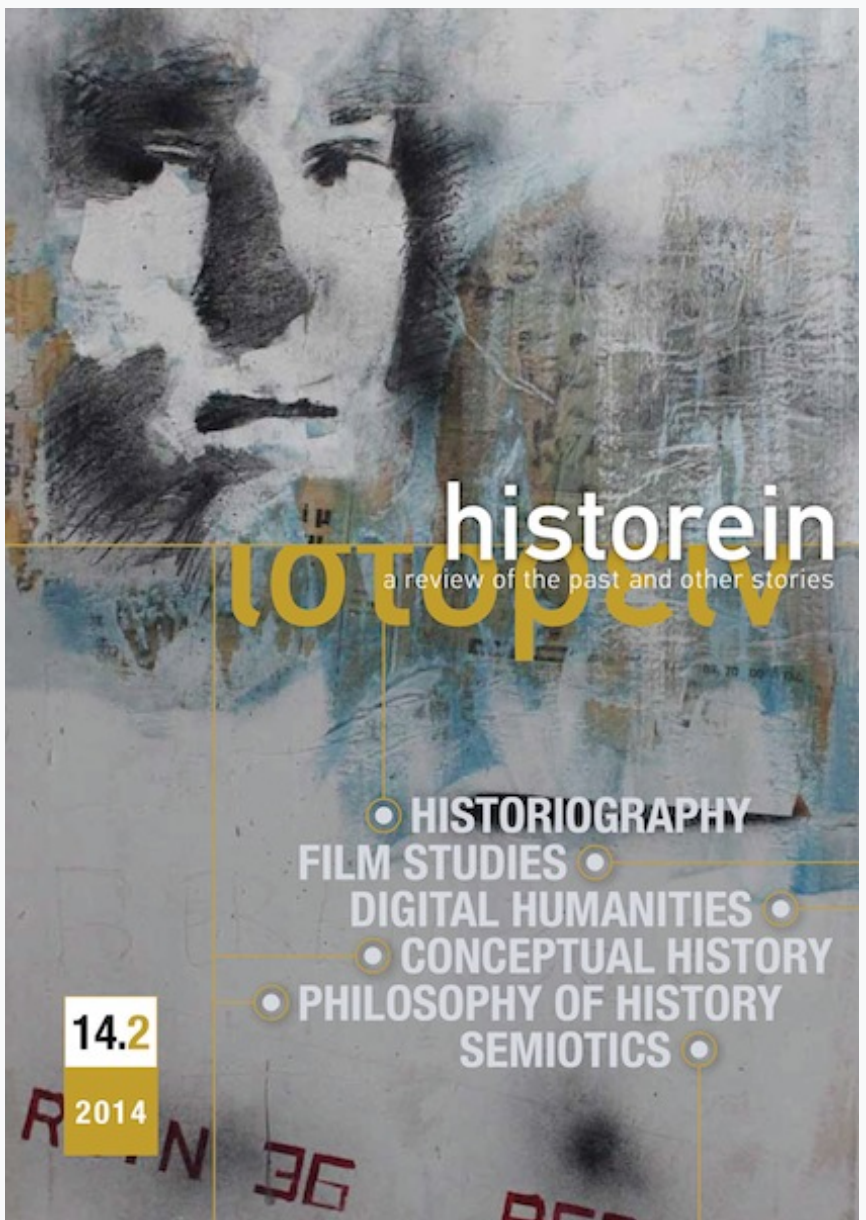

\section{Review essay: A surfeit of violence?}

Haris Exertzoglou

doi: $\underline{10.12681 / \text { historein.266 }}$

Copyright $\odot$ 2015, Haris Exertzoglou

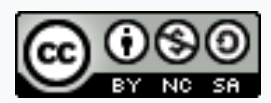

This work is licensed under a Creative Commons Attribution-NonCommercialShareAlike 4.0.

\section{To cite this article:}

Exertzoglou, H. (2014). Review essay: A surfeit of violence?. Historein, 14(2), 103-111.

https://doi.org/10.12681/historein.266 


\section{REVIEW ESSAYS}

\section{A surfeit of violence?}

\author{
Ayșe Ozil, Orthodox Christians in \\ the Late Ottoman Empire: A Study \\ of Communal Relations in Anatolia,
} London: Routledge, 2013. 186 pp.

Nicholas Doumanis, Before

the Nation: Muslim-Christian

Coexistence and its Destruction in

the Late Ottoman Anatolia, Oxford:

Oxford University Press, 2013. 226 pp.

Ryan Gingeras, Sorrowful Shores:

Violence, Ethnicity and the End of

the Ottoman Empire, 1912-1923,

Oxford: Oxford University Press,

2011. 256 pp.

\section{Haris Exertzoglou}

University of the Aegean

In the former Ottoman dominions, cataclysmic events followed the end of the First World War, particularly the collapse of the Young Turk administration, the division of the Ottoman empire in 1919 by foreign armies, the treaty of Sèvres, the occupation of Smyrna by the Greek army, the long Greek-Turkish war and the exchange of populations between Greece and Turkey ratified by the Lausanne treaty in 1923. The complete political and spatial reshaping of the region brought about by these events considerably affected all major and minor population groups living in the empire. The end of the war and the population exchange bore ambivalent meaning, as for the Turks they signified a glorious victory and the springboard of the new Turkish Republic towards a path for progress unhindered by the Ottoman past and irritating non-Muslims. For the Greeks, these events represented a Megali Katastrofi (Great Disaster), a major national destruction in modern Greek history, which had the side effect of bringing the bulk of Ottoman Greeks who survived the war within the borders of the Greek national state. These events were integrated in the Greek and Turkish national narratives in different and antagonistic ways, yet both share common rhetorical strategies: Greeks and Turks are understood as coherent and homogenous bodies pitted against each other in a life-or-death struggle. Greek historians underlined the barbarity of the Turks, holding them responsible for the massacre of hundreds of thousands of Christians, while Turkish historians retaliated on the same ground arguing that Muslims suffered even more in a war of crucial importance for their future. In addition, Christian minorities (both Armenian and Christian Orthodox) were blamed for seditious and treacherous activities against a benevolent state that was fighting for its existence. These old narratives remained practically unchanged and affected the collective historical perception in both countries for decades. Generations of Greeks and Turks were raised in an atmosphere of mutual distrust, if not open animosity, which subsequent political relations between Greece and Turkey did not help to calm. However, in the last ten or twenty years a growing number of scholars - Greeks, Turks and others - have begun to raise important issues about the nature of late Ottoman society. Recent research has underlined the complexity of interreligious and ethnic relations in Ottoman society, particularly during the nineteenth century when new national affiliations were mobilised under the influence of nationalism and 
the dynamics of economic and political modernisation. One issue of major concern is the extent of violence and the immense number of civilian casualties in the Ottoman lands during the final agonising years of the empire. Mainstream historical wisdom in Greece and Turkey consistently avoids perplex issues and insists on using clear-cut and coherent national bodies as objects of respective national(ist) narratives. New approaches should invest in more nuanced perspectives that take into account the complexity of late Ottoman society, the dynamics of change as well as the variety of local contexts. Of course, the relation between the local and the national or imperial level is intricate because not all local cases can be reduced to the imperial level nor can this level be seen as the sum of localised events. In any case, it is time to rethink sensitive issues, particularly those related to limit events. I do not believe that we can reach conclusive answers to satisfy all sides, due to the highly politicised nature of these events, but again uncertainty is embedded in historical knowledge. The crucial thing is to extend historical research and rethink Ottoman society. The studies by Ayşe Ozil, Ryan Gingeras and Nicholas Doumanis provide the niche to do this. Although these studies treat different issues, they somehow overlap, allowing the reader to rethink the end of the Ottoman empire and the rise of the nation-state in novel ways.

\section{Ozil's Orthodox Christians in the late Ottoman} Empire provides an interesting perspective regarding communal life of Christian Orthodox or Greek communities in the Ottoman empire, using the communities of the South Marmara coast as a case in point. ${ }^{1}$ Against a Greek historiographical background which posits these communities as coherent and separate from other religious communities, Ozil provides a much more complicated picture which questions well-defined boundaries. Local adminis- tration, finance and taxation, law and the legal corporate status of communal institutions, as well as issues of nationality, are discussed in detail, with the use of both Greek and Ottoman primary sources. According to Ozil, the emergence of a distinct Christian Orthodox institutional network (churches, schools, philanthropic institutions) and administrative communal bodies (koinotites) responsible for managing these institutions, did not result in a clear-cut milli homogenous space in which all Christian Orthodox were integrated. Despite the existence of this institutional sphere, local Christians reacted in a variety of ways, with some of them directly opposing the Ottoman Christian authorities and community structures. Ozil refers to numerous cases of Christian Orthodox individuals who challenged the Ottoman Christian authorities in matters relating to taxation, legal authority or even nationality. In fact, as the author claims, Christian Orthodox individuals were not necessarily part of Christian Orthodox communes, which were exclusive bodies with membership being conditional on specific requirements, including the payment of property tax and the holding of Ottoman nationality. Although Christian Orthodox institutions were open to Ottoman Christians, there were many cases where Ottoman Christian individuals used parallel structures, such as Ottoman courts, Ottoman or missionary schools, or simply failed to see any benefit in using Ottoman Christian structures, with the refusal of many peasants to send their children to school being a case in point. Existing choices involved tension and practical difficulties and local Christians did not necessarily take predictable steps. For example, although Hellenic nationality was available to Ottoman Christians, those opting for it found themselves in tension with Christians holding Ottoman nationality. In the case of communal administration, this was more or less evident, but this tension struck a precarious balance when more dramatic events 
took place as, for example, the anti-Hellenic boycott following the declaration of Cretan independence in 1912. Then Christian Ottoman and Hellenic nationals found themselves frequently at odds. Finally, Ozil highlights the tensions regarding the legal corporate status of Christian Orthodox structures as far as Ottoman law and administration are concerned. This was a complex legal and political issue. Due to the fact that the Ottoman legal system did not recognise corporate identity and the Ottoman state extended institutional authority to particular individuals, such as ecclesiastical or lay leaders, these communal structures functioned in a legal lacuna. Even when the Ottoman state introduced new legislation on corporate bodies in 1913 that acknowledged the right to own and transfer revenue-generating property in towns and villages, the move was incomplete. Non-Muslim institutions, although not explicitly named, were granted ownership rights but the conditions of ownership remained insecure as they were subject to various administrative restrictions. Furthermore, not all communal property was included. In addition, the state did not share its control of many legal matters, such as criminal cases, with the Christian authorities and did not grant much authority to the Christian notables who participated in Ottoman provincial administrations, where decision making rested with Muslim officials. Overall, the study provides a fresh perspective by advancing one step further recent approaches that have questioned the coherence and homogeneity of Ottoman Christian "communities", underlined existing cultural and social differences and stressed the policies of Hellenisation in producing a solid national body. Despite their critical thrust, these approaches somehow seem to accept that these policies were effective and that the making of "national" [milli] structures eventually produced the Christian Orthodox-cum-Greek national community because the Ottoman framework was actually conducive to this. Ozil does not suggest that the process of nationalising Ottoman Christians was absent or unsuccessful but that this framework ran against the consolidation of communal institutions at a local level. The South Marmara case provides a different and useful perspective to rethink the limits of community building within the parameters of the Ottoman legal and political landscape. Whether one should jump to generalisations is a different matter, though, because this is not the first time that we have been warned of the complexities of late Ottoman history.

If community structures failed to produce solid boundaries between the Christian Orthodox and their Muslim and other non-Muslim neighbours, the question arises about the kind of relations that took shape on a local level between different religious groups in times of nationalist agitation. Did forms of coexistence survive in the face of nationalist agitation and is there a point in time where these forms proved unable to sustain some kind of solidarity and mutual help when open armed conflict reached almost every part of the Ottoman dominion between 1912 and 1922? I believe these are the sort of questions one has to bear in mind when reading Nicholas Doumanis' book Before the Nation. The study is based on extensive research in the oral tradition archive of the Centre for Asia Minor Studies, which hosts an impressive and unique collection of testimonies of first- and second-generation Christian refugees from Anatolia. Doumanis used this material to reconstruct Asia Minor histories through the recollections of individual refugees, suggesting that these memories should not be neglected particularly because they contain expressions of sympathy and affection for neighbouring Turks, which runs against the official Greek narrative emphasising Turkish barbarity. This call for the rehabilitation of popular memory is interest- 
ing but it also raises crucial epistemological issues regarding the limits of representation and the complex and nonlinear relation of history and memory. Refugee memories strike a coherent narrative: beginning in the times of Abdul Hamid, "the Ottoman belle époque", where coexistence between Christians and Muslims was an everyday reality, this is followed by escalating tensions and ends with the Great Disaster and the final removal of Christians from their ancestral homes. In the years before 1912, Ottoman Christians benefited from a tolerant sultanic regime which allowed them to prosper whereas Christians and Muslims shared mutual respect and some common practices which sustained the social order at local level. The Young Turkish regime brought major changes which increased state interference and politicised society, thus undermining existing intercommunal relations. The outbreak of the Balkan wars seriously affected intercommunal relations in Anatolia as Muslim refugees, particularly Muslim Cretans, played a major role in the radicalisation of Muslim reactions and the animosity between Anatolian Christians and Muslims. Experiences of deportation, forced marches and deprivation during the First World War further shaped the reactions of many Greek refugees towards the Ottoman state, according to testimonies. The reciprocity of violence during a decade of warfare involving both Christian and Muslims made reconciliation impossible. Christian Muslim coexistence, which proved functional in Anatolia but not necessarily so elsewhere in the empire, collapsed within years under the weight of extended warfare. Bad times replaced good times and existing forms of coexistence dissipated amid extensive violence. However, many refugees kept the memory of the good relations with their Muslim neighbours intact and attributed the loss of their homelands and the loss of life of many of their coreligionists to political conjunctures, high politics, imperial designs and outsiders, people foreign to their towns and villages and not to the actions of their "own Turks".

Refugee memories exonerating "our Turks" and putting the blame on outsiders is probably a way of negotiating with the traumatic past. Refugee memory, selective as memory always is, rescued the "good Turk" as part of the familiar but now lost homeland. On the other hand, these memories seem to repress or simply ignore other facets of the past, including social conflict and social hierarchies or even the enlistment of Ottoman Christians in the Greek army or paramilitary bands. Even if the questionnaire addressed to them by the interviewers of the Centre for Asia Minor Studies ignored such issues, respondents could bring them out themselves. I do not suggest that reference to "good Turks" were completely imaginary; far from it. There were many cases where Turks helped Greeks or tried to save them. I simply refer to the fact that refugee memories seem to have followed a narrative pattern which is important in its own right and not because they corresponded to actual facts. If these memories are of value, as I believe they are, it is because they allow us to consider how refugees restructured their emotional disposition in relation to their contemporary position and life in a new country. For that purpose, the negotiation of the past symbolised a space of stability and was vital for many Ottoman Greek refugees who aspired or hoped to reach some kind of stability and normality with their life in Greece. One should always remember that for many refugee families it took decades before they left the crowded temporary settlements in which the Greek government placed them after their arrival in Greece in 1922. In addition, refugees were directly involved in Greek politics and many of them were implicated with the Greek left, suffering immensely during and after the Greek Civil War, as all people on the 
left did. In other words, this reviewer opines that the memories of the refugees probably reveal more about social life in post-1922 Greece than the actual Ottoman past. Cast in the metaphoric language of nostalgia, refugee memory tended to idealise the past as a comment to what was usually an unenviable life in the squalor of the urban settlements where most refugee families lived.

Intercommunal relations and long coexistence did not stop the destruction of the "multiethnic" Ottoman society. Even if ethnic difference alone is not the cause of violence, as Doumanis does not cease to repeat, Ottoman Anatolia was the arena of serious fighting, not only between official armies but also between paramilitary bands, though many times the line between the two were blurred. Ryan Gingeras' Sorrowful Shores shows how complicated this fighting actually was because it did not simply involve "Greeks and Turks", or "Muslims and Christians", but it also divided to some considerable extent the Muslim population of Western Asia Minor. The book focuses on the South Marmara area and the villayet of Hüdavendigar and, from this aspect, it refers to the same space as Ozil's study. Gingeras brings to the fore the networks of Muslim immigrants from the Caucasus (Circassians, Dagestanis) and the Balkan provinces that settled in South Marmara, where they engaged in banditry and, during the long wars of 1912-1922, in paramilitary activity. The allegiance of these armed bands oscillated according to immediate material and political concerns. Many were used to protect the rich Muslim landlords of the region while others practiced banditry for subsistence. During the war many were involved in the paramilitary organisations set up by the Young Turks, even in the infamous Teşkilat-i Mahsusa (Special Organisation), and participated in the campaigns against Christian Orthodox and Armenian civilians. The collapse of the Ottoman empire was a watershed. Foreign invasions, particularly the Greek occupation of Smyrna, the emergence of the Kemalist movement, the huge civilian casualties due to Christian massacres, and deportation and deprivation, reshaped local allegiances and increased Muslim anxieties about the future of the area. This conjuncture, however, involved more than one choice. Local Muslim groups constantly negotiated their political affiliation not only with the Kemalist nationalist movement but also with Islamic and loyalist forces. In this context, as Gingeras clearly shows, conflict between nationalist forces and Muslim militias subscribing to different political agendas was not uncommon. The study discusses in some depth the conflict between Circassian paramilitary bands and Turkish nationalist forces in Hüdavendigar after the treaty of Sèvres as well as the different political agendas with which different groups of Circassians associated themselves with: loyalist and Islamic affiliations, cooperation with the Greek army, plans for regional autonomy as well direct association with Turkish nationalists.

Sorrowful Shores allows the reader to understand the complicate situation on a local scale, where conflicts and shifting allegiances played a vital role in the radicalisation of the war that involved paramilitary groups affiliated to the various ethnoreligious groups. At this point, some crucial questions arise. Given the extent of the war and the immense loss of life, one wonders whether the emphasis on paramilitary activity exonerates official Ottoman state policies of ethnic cleansing, particularly the actions against the Armenians during the First World War. It is not the opinion of this reviewer that Gingeras follows this line of argumentation closely, though there are moments where one gets the impression that he accommodates the official Turkish thesis according to which Ottoman Christians, both Orthodox 
and Armenians, posed a threat to the integrity of the empire, which was actually the official excuse for mass deportations. Although there were many cases where Ottoman Christians supported the enemies of the empire - for example, Armenian volunteers joined the Russian army and Ottoman Greeks enlisted in the Greek army of occupation - the bulk of Christians stood aloof from politics. Yet, in the exigency of war, the Young Turk leadership did not hesitate to accuse Christians of treason and acted accordingly, ordering mass forced expulsions which ended in the death of hundreds of thousands, particularly Armenians. Hundreds of thousands of civilians suffered because this leadership applied the unjustifiable principle of collective responsibility which, according to many historians, was simply part of a major effort to control "unruly" minorities. Thus, generalising statements about the conduct of Christians or Muslims during the war is certainly counterproductive, as the case of the Muslims of the South Marmara area, which Gingeras discuss in detail, clearly shows. Leaving this issue aside for a moment, one wonders about the effects of this prolonged war on a local level. Was it possible that this bitter war unleashed local conflicts associated with local interests and vendettas that were conducted by paramilitary if not criminal bands? Does the local scale put in sharp relief the nature of existing antagonisms and conflict as being devoid of formal ideological content? If this is the case, how is this scale articulated with the national or imperial scale in which political and ideological agendas are far more emphasised as the basis for mass mobilisation? What was the role of these agendas in the outbreak of conflicts in the South Marmara region? Although Gingeras focuses on the social networks of Circassians and other Muslim groups, he does not neglect to discuss ideological and political issues, albeit not extensively.
The studies by Ozil, Gingeras and Doumanis are food for thought. Although they focus on different issues and treat slightly different though overlapping periods, they somehow bring to the fore some of the major issues of the late Ottoman era: imperial reorganisation, nationalist building, ethnic and religious boundaries, and warfare and violence against civilians. Reading these books, one could not stop wondering about the excessively violent nature of the long war of 1912-1922. The issues here are far from clear. Ozil suggests that Ottoman Christians did not necessarily identify with Orthodox structures and that a homogenous Christian Orthodox-Greek space did not emerge; Doumanis underlines the feelings of affection which Ottoman Christians harboured for their Turkish neighbours as well as the sense that these feelings were reciprocated. How then can one understand the excessive violence which engulfed Ottoman territories during the decade of war from 1912-1922? Should one be led to believe that if nationalist agendas were more effective, they would have caused more violence even if the big wars did not happen? Was this kind of violence specific to the internal dynamics of Ottoman society? Any answer to these questions must take into account that nationalist agendas were not necessarily secessionist but also integrative, as the project of Greek-Ottoman cooperation [ $\varepsilon \lambda \eta n v o-o \theta \omega \mu a v i \sigma \mu o ́ c]$ suggests. As for violence itself, one should also remember that it was already evident in parts of the Ottoman dominion long before the outbreak of the Balkan wars, though not in Asia Minor, which is the subject of the three studies under consideration. Ottoman Macedonia, for example, had seen its fair share of violence since the 1870s, though this conflict pitted Greek against Bulgarian bands which shared the Orthodox religion but subscribed to different nationalist agendas. What made the situation more complicated is the way external and internal fac- 
tors responsible for the outbreak of violence overlapped. Ottoman imperial decline, nationalist agitation and European imperialist designs were part of the same political and power texture which interacted with local conditions and affected local allegiances throughout the last half-century of the empire. In this context there were different patterns of local reactions to broader dynamics, as Gingeras shows. To put it schematically, one may assume that these dynamics were responsible for the radicalisation of ethnic and national antagonisms that took place in the final years of the empire. The exigencies of war and the destruction of existing patterns of trust and coexistence were the effect of the gradual radicalisation of the war, which remained inconclusive long enough to test political affiliations and practices and reshape identities. The destruction of Armenians, the persecutions and expulsion of Ottoman Greeks and the exodus of Muslims from Macedonia and Thrace were the bitter outcome of a long war which engulfed all the major "ethnoreligious" groups of the empire. It was the war itself, the unpredictability of chaos, which created the conditions of excessive brutality and reshaped ethnic identities. On the other hand, a broader perspective of the big picture does not necessarily suffice to explain the dynamics of local societies where factors that cannot be easily reduced to the big picture played a significant part in the shaping of local events. In other words, one must be prepared to face the possibility that the effects of the war on a local level developed the kind of dynamic that cannot be reduced to a major primary cause - interstate warfare. In this respect the local and the "imperial" level were interwoven, but not in a commensurate fashion. "Outsiders" like the Muslim Cretans or the Circassians, who were forced to move out of their homelands in Crete and the northern Caucasus, reshaped their identities and affected the social order in western Asia Minor as a response to local circumstances. Bitter experiences before their arrival in Asia Minor cannot explain the political choices of these groups in Asia Minor unless one takes into consideration how they fitted or did not fit into the social and cultural fabric of this new environment. In this light, the local scale can better inform the dynamics of violence without reducing the phenomenon to the state of general radicalisation of practices and consciousness which the "long war" of 1912-1922 brought about.

However helpful the above hypothesis might be, it needs qualification to prevent it ending up as a kind of generalisation that explains less than it reveals. What pitfalls are involved here? I want to address this by discussing violence against civilians in the late Ottoman period, an issue which I believe historians of the period should take into consideration. One should never forget the high number of civilian casualties, mostly Christians but also Muslims, who were victims of massacres, forced migration, hunger and disease during the course of this long war. One should also not forget that these deaths were not accidental but were, to one degree or another, the outcome of specific military and political decisions. How can historians deal with what in the modern official idiom of warfare is called "collateral damage", especially on this immense scale? Counting bodies or minimising the significance of these decisions is morally unacceptable. Taking sides is a clear-cut choice but insufficient. In the context of the long war of 1912-1922, all sides were implicated to one degree or another in atrocities and brutal practices in defence of what they believed were their "natural rights", which in the context of the period under consideration seemed reasonable to those supporting them. Of course, this does not mean we equate victims and perpetrators, as, for example, members of the Teskilat-i Mahsusa with Ottoman Armenian civilians. However, in this chang- 
ing war scene, the lines between victims and perpetrators were sometimes blurred as the victim became the perpetrator and vice versa, as happened during the Greek-Turkish war. Is it possible to construe a coherent narrative which does justice to all sides and, particularly, to all victims of the war? Most probably this is impossible considering the political nature of history writing. Yet even if we were to reach a point where a number of solid studies are available - and the studies under review certainly merit this distinction - can we be certain that all historiographical and moral issues involved in the study of this particular past would be resolved? This rhetorical question simply underlines the fact that historical interpretations, which actually purport to tame the chaos of the past, cannot satisfactorily address moral and even historiographical issues, particularly when historical events of this magnitude are considered, on the basis of the historical record alone. Do interpretations that take into account forms of coexistence, the complexities of local contexts, or retrospective negotiations of the past actually construe a kind of normalising discourse which seeks to understand and therefore to forgive or condone? Does understanding equal forgiveness? Does normalisation of the past equal mourning? Or should one always reject reconciliation and exclude normalising interpretations, insisting instead on the kind of theodicy which informed nationalist narratives? Issues such as these always imply a level of philosophical and political reflection beyond the historical record itself and are therefore beyond proof, strictly speaking. This is the unstable ground that most historians fear to tread or simply avoid; yet it is full of potential.

I want to take this argument one step further by addressing two related issues. Historians of the late Ottoman period usually repress philosophical and epistemological issues in their work, follow the record and try to set the story straight. Despite tons of new evidence, consensus on these issues is still far away and probably it will never occur. Of course, one could counter this by pointing to the kind of rational explanation which, based on historical facts, could provide satisfactory interpretations. This sounds right and most of the time this seems to be acceptable for historians. Yet, the question remains whether rational explanations are really sufficient to understand tragic events such as those under consideration, based on historical facts alone. Can we expect to find rational explanations about the motives and interests behind acts of excessive violence? Rather, what seems to be at stake are the limits of rationality, particularly this kind of rationality that pits reason and emotion as exact opposites and is totally unreceptive to any consideration regarding the complicated and interactive relation between the two. Thus even if all rational factors (motives, interests, social dynamics, etc.) are added up, there remains a residue which cannot be explained rationally. As with many other limit events, the search for motives and interests provides only half answers. What historians actually see is the effect of human actions and not the kind of psychocultural workings behind these actions, which usually remain unrecorded. People act and react in ways that challenge the concept of transparent, rational motivation, which predicated certain acts and not others. Even if we broaden the scope of motivation and acknowledge that there were motivations of a different nature at work simultaneously (local power games, restructured identities, crisis of personality, strategies of subsistence), nonetheless it is difficult to explain adequately the extent of violence against civilians that took place in the long war of 1912-1922. Motive as a mode of causality simply fails to explain everything at this level. On the other hand, an emphasis on motivation and rationality does not 
adequately address individual suffering and loss because attention is directed to all sorts of political or military decisions which actually shaped the course of "big" events. In this context, individual states of emotion usually are of no interest to historians unless they can be considered as expressions of a broader phenomenon. There are epistemological consequences in this choice regarding disciplinary boundaries that must be put into sharp relief. It is well known that testimonies change with the passing of time, that they tend to be inaccurate in some important or less important details, that they integrate facts and other memories which were not available when the events to which testimonies refer occurred. For these reasons, historians tend to trivialise the value of testimonies as a reliable source of historical knowledge and, more generally, tend to overemphasise the distinction of memory and (true) history. In this manner, historians also make concrete judgments about the boundaries of history as a discipline that deals with the past in specific ways and uses specific material for the historiographical operation. Here the kind of material which historians seem to value most, at least theoretically, is "nonintentional" evidence which was not made with an eye to the future. In contrast, individual testimonies are often held suspect as a means of justification of the acts and intentions of particular individuals. Of course, the distinction between "intentional" and "nonintentional" evidence is fragile to say the least. Historians use various kinds of material without being, most of the time, in a position to distinguish between these two categories, or even think they are worth distinguishing. Although there is evidence which might be deemed impersonal and part of everyday stuff, like food prices, birth rates, exchange rates or train schedules, their value is only relative to the major issues which historians seek to address. In the face of limit events in particular, this kind of evi- dence is only partially helpful. Train schedules to Auschwitz, for example, were indicative of the mass transportations of Jews there, but in itself this evidence falls short of explaining the Holocaust. We knew about the Nazi genocide long before we had knowledge of the train schedules to Auschwitz. Part of our knowledge of the Holocaust or of other extreme events comes from individual victim testimonies which, subjective and emotional as they are, cannot be squeezed into broader categories of meaning. What will be done with these testimonies? What's more, what can be done with the voices that have left no trace in the historical record? Should individual testimony be taken at face value, as a monument to the suffering self, or will it be relevant to history only in its most superficial and impressionistic level? Should we guard disciplinary boundaries which today appear obsolete and restrict ourselves from exploring new possibilities and alternatives of historical thinking? If historians are not content with this situation, if they somehow wish to address issues related to individual testimonies of victims of extreme events, then they need to embark on the kind of philosophical and aesthetic reflection which, though remote from the well-trodden fields of historical empirical work, is perhaps capable of making the understanding of violence, suffering and death more possible.

NOTE

1 I am aware of the intricacies implicated in these terms, but for the purposes of this review I will use them interchangeably. 